\title{
The Effects of "Search Engine Optimization" on Marketing of Diving Companies in Bali
}

\author{
Iola Astried Karisma1, I Nyoman Darma Putra², and Agung Suryawan Wiranatha \\ ${ }^{1}$ Master Student in Tourism Program, Udayana University - Bali \\ ${ }^{2}$ Centre of Excellent in Tourism, Udayana University - Bali \\ Corresponding author: iola.karism@gmail.com
}

\begin{abstract}
ARTICLE INFO
ABSTRACT

Received

28 February 2019

Accepted

18 March 2019

Available online

31 March 2019

The strategic location of the island of Bali which is surrounded by sea has a great potential for people in Bali to establish a diving company. Some diving companies in Bali have made various strategies to compete offering diving tour packages. Marketing through the internet is the best way that most diving companies in Bali have recently taken. However, to be able to compete with other similar companies on the internet, the website must be easily accessible to internet users, i.e. by appearing on the first page of the Google search engine. SEO or search engine optimization is an internet marketing strategy that serves to increase website visibility by targeting certain keywords. The use of SEO can have a positive impact on increasing online sales, increasing website visibility and brand awareness on the internet. This study aims to analyze the extent to which SEO techniques have a positive impact on the marketing of diving tourism in Bali through the internet, using quantitative descriptive methods. The research was conducted in three selected companies, namely Bali Diving, Atlantis Dune, and Scuba Adventure. The results of the study showed that diving companies in Bali have obtained all the positive impacts of SEO. These impacts were increasing website visibility, brand awareness, and sales.
\end{abstract}

Keywords: Diving in Bali, Internet Marketing, SEO, Bali Tourism.

\section{INTRODUCTION}

\section{Background}

The beauty of the beach of Bali Island has great potential for developing business in the field of marine tourism, http://ojs.unud.ac.id/index.php/eot especially diving operator. Each diving spot in Bali presents its own uniqueness to explore, such as the Manta ray center in Nusa Penida, underwater garden in Pemuteran, and ship wreck spots in Amed and Tulamben (Asia Web Direct, 2018). e-ISSN: 2407-392X. p-ISSN: 2541-0857 
The potential of diving tourism in Bali Island can actually be developed in almost all regencies. The big contribution is also given by the island of Bali in an effort to increase Indonesia's foreign exchange, with most of its income coming from the marine tourism sector, especially diving and snorkeling activities (Hidayah, Sunarti and Hakim, 2017). According to Wiranatha, Suryawardani, Bendesa, \& Antara (2016), the level of satisfaction of foreign tourists in diving activities in Bali were mostly satisfied, ranging between $78.5 \%$ and $95.6 \%$. The highest level of satisfaction was dive guides $(95.6 \%)$ and the lowest was accessibility to the diving sites $(78.5 \%)$.

The magnitude of the diving business potential in Bali raises several foreign and local companies that compete to offer diving tour packages in Bali. Internet marketing is the most effective way chosen by several diving companies in Bali to compete in marketing diving tourism packages. SEO or search engine optimization is one of the internet marketing strategies that recently began to be popular in the community, as well as in the field of diving tourism. SEO strategies are able to help several websites of diving companies in Bali appear on the first page of the Google search engine, so as to be able to compete offering diving packages via the internet. SEO is a website http://ojs.unud.ac.id/index.php/eot optimization strategy by the creation of content and using certain keywords so that websites can be easily found on search engine pages (Rahman, 2015). The use of SEO can have a positive impact on the company, especially in increasing website visibility, brand awareness, and sales of company products.

According to the ranking of the diving websites on the Google page, there are three diving companies that always succeed in occupying the first page of the Google search engine, with keywords 'dive in Bali' and 'diving in Bali'. The three companies are Adventure Scuba Diving, Atlantis Dune, and Bali Diving. Through these companies, samples were taken to prove the positive impact of SEO utilization on the diving tourism business competition in Bali through the internet and to find out which of the most influential impacts for each diving company. Currently there is still little research on the impact of SEO utilization on the diving business so that this research is expected to be able to add references to research on SEO in the tourism sector.

\section{METHODOLOGY}

\section{Theories}

The theory of internet marketing was used in this research. According to Wong (2010), internet marketing is a series of activities carried out by a 
company to market a product or service using the internet. Internet marketing provides convenience both in terms of time efficiency, costs, and geographical boundaries of a region. The growth of internet users in each country is also the basis for the formation of internet marketing ideas in various fields, including diving businesses in Bali. One of internet marketing startegy that is used by the diving companies is SEO strategy. SEO stands for search engine optimization, which is one of the internet marketing strategies by optimizing the quality of the website, so that the website can be easily found by information seekers on the search engine pages (Rahman, 2015).

According to Hakim (2011) SEO strategies can be divided into 2, namely on-page optimization and off-page optimization. On-page technique is a technique used to optimize website elements, namely title tags, description tags, urls, and page content. On-page techniques differ from off-page optimization techniques, namely optimization techniques outside the website elements. Off-page techniques are usually in the form of spreading links in the form of social media publications, blogs, and threads in online forums.
SEO strategies can provide several positive effects, namely increasing website visibility on the internet, increasing brand awareness, and selling products (Alam, 2015 in Satibi, Suharyono, \& Abdillah, 2017). The three positive effects of SEO are then used as variables in this study, where each variable consists of 2 to 4 indicators. Brand awareness variable according to Homburg, Klarmann, \& Schmitt (2010) can be divided into 4 parts, namely top of mind, brand recall, brand recognition, and brand knowledge. Furthermore, according to Joubert, Garg, \& Pellissier (2004), an increase in sales can be seen from the company's financial profitability. Variables for increasing website visibility can be measured from global rank and ranking on SERP. Indicators of increasing website visibility can be checked online and periodically using the SEO checking tool, namely alexa.com

\section{Research Methods}

The research uses descriptive quantitative method, by conducting a survey directly into the field using documentation studies, questionnaires and interview guidelines. Questionnaires were distributed to consumers of the diving companies and made to measure the brand awareness level variables. The interview guide was used to interview the companies 
to measure the success of product sales. Checking the quality of the website was also carried out every day for a month to determine the development of the websites' visibility after using SEO.

All variables were measured in order to answer research questions, namely what are the effects of SEO utilization on the competition of diving businesses in Bali, as well as the most influential effects for each diving company. The data obtained were then described descriptively, presented in the form of graphs and tables, and tested for its validity and reliability so that it is feasible to be used as research data.

\section{RESULTS AND DISCUSSION}

All diving companies, namely Adventure Scuba Diving, Atlantis Dune, and Bali Diving have used on-page SEO and off-page optimization strategies. Offpage optimization techniques are shown through the number of backlinks or the dissemination of website information through social media, blogs, and online forums. Bali Diving has around 52 backlinks, Atlantis Dune 107 backlinks, and Adventure Scuba Diving has the smallest number of backlinks, as many as 7 backlinks every month. Furthermore, the on-page SEO technique is demonstrated through the creation of website elements that match the keywords of diving company products, namely the keywords 'diving in Bali' and 'dive in Bali'. The use of keywords in website elements can be elaborated as follows:

Table 1. Use of Keywords on Website Elements of the Diving Companies

\begin{tabular}{|c|c|c|c|}
\hline Domain & $\begin{array}{l}\text { www.atlanti } \\
\text { s-bali- } \\
\text { diving.com }\end{array}$ & $\begin{array}{l}\text { www.balid } \\
\text { iving.com }\end{array}$ & $\begin{array}{l}\text { www.adven } \\
\text { ture-scuba- } \\
\text { diving.com }\end{array}$ \\
\hline $\begin{array}{l}\text { Meta } \\
\text { Title }\end{array}$ & $\begin{array}{l}\text { Full Pack } \\
\text { Bali Dive } \\
\text { Trip | Scuba } \\
\text { Dive Bali | } \\
\text { Atlantis Bali } \\
\text { Diving }\end{array}$ & $\begin{array}{l}\text { Bali } \\
\text { Diving; } \\
\text { PADI } \\
\text { Diving } \\
\text { courses, } \\
\text { Scuba } \\
\text { Diving } \\
\text { Bali }\end{array}$ & $\begin{array}{l}\text { Adventure } \\
\text { Scuba } \\
\text { Diving Bali }\end{array}$ \\
\hline $\begin{array}{l}\text { Meta } \\
\text { Descript } \\
\text { ion }\end{array}$ & $\begin{array}{l}\text { Diving in } \\
\text { Bali with } \\
\text { total ease to } \\
\text { enjoy } \\
\text { sighting of } \\
\text { exotic marine } \\
\text { life. Explore } \\
\text { best scuba } \\
\text { dive Bali spot } \\
\text { with Atlantis } \\
\text { International } \\
\text { Bali, PADI } \\
\text { certified, } \\
\text { TripAdvisor } \\
5 \\
\text { Take our Bali } \\
\text { diving } \\
\text { holiday } \\
\text { package for } \\
\text { all level of } \\
\text { divers from } \\
\text { 1.620K/pax. } \\
\text { Full } \\
\text { equipment. } \\
\text { FREE } \\
\text { pickup. } \\
\text { Multilingual } \\
\text { guide. BOOK } \\
\text { NOW. }\end{array}$ & $\begin{array}{l}\text { Bali } \\
\text { Diving is } \\
\text { one of } \\
\text { Bali's } \\
\text { longest } \\
\text { established } \\
\text { internation } \\
\text { ally } \\
\text { accredited } \\
\text { Dive } \\
\text { Centers } \\
\text { located in } \\
\text { Sanur, } \\
\text { Bali. Try } \\
\text { dive, } \\
\text { Courses, } \\
\text { Fun } \\
\text { Diving, } \\
\text { Snorkeling } \\
\text {. }\end{array}$ & $\begin{array}{l}\text { A small } \\
\text { company } \\
\text { with a big } \\
\text { personality! } \\
\text { Adventure } \\
\text { Scuba } \\
\text { Diving Bali } \\
\text { is a PADI } \\
\text { dive centre } \\
\text { based in } \\
\text { Seminyak, } \\
\text { Bali. }\end{array}$ \\
\hline $\begin{array}{l}\text { Body } \\
\text { Content }\end{array}$ & $\begin{array}{l}\text { Scuba Dive } \\
\text { Bali is An } \\
\text { Unforgettable } \\
\text { Experience } \\
\text { And Dune }\end{array}$ & $\begin{array}{l}\text { Welcome } \\
\text { To Bali } \\
\text { Diving - } \\
\text { Bali } \\
\text { Diving is }\end{array}$ & $\begin{array}{lr}\text { Beginner or } \\
\text { First Time }- \\
\text { Not } \\
\text { about } \\
\text { diving }\end{array}$ \\
\hline
\end{tabular}




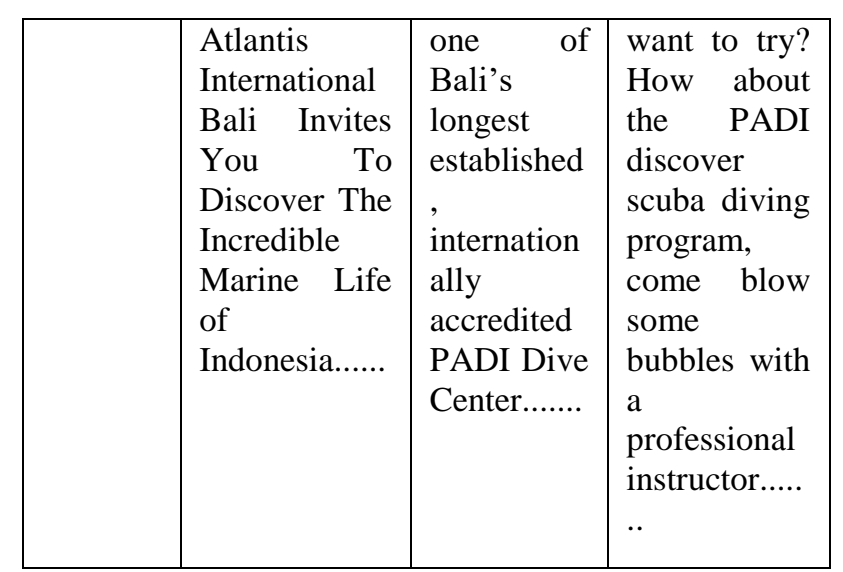

Source: moz.com (2018)

The table above shows that Atlantis Dune, Bali Diving and Adventure Scuba Diving have arranged the content and elements of their websites in such a way by using words that are relevant to the keywords "Diving in Bali" and "Dive in Bali". The frequency of repetition of the words "dive", "diving" and "Bali" on page content, URL, meta title and description can have a positive effect on the ranking of the website on the google search engine page which automatically increases the number of visitors. From Table 1, Bali Diving looks most detailed in arranging keywords in website elements. Conversely, Scuba Diving Adventure seems to be at the least that optimizing the elements of its website by using the keywords "dive in Bali" and "diving in Bali".

\section{Increasing Website Visibility}

The use of the keywords "diving in Bali" and "dive in Bali" on the website can signal to Google that the Atlantis Dune http://ojs.unud.ac.id/index.php/eot website, Bali Diving, and Adventure Scuba Diving have the right website content to be recommended to internet users who are looking for website content information. Spreading links through social media, articles, blogs and online forums on topics and the use of the right keywords can attract the attention of internet users. The use of SEO to compile the website content of Atlantis Dune, Bali Diving, and Adventure Scuba Diving is the right way to attract prospective customers who use google.com as a tool to search for information about diving in Bali.

Information about diving in Bali; the higher the ranking of the company's website, the greater the possibility of a website to be visited by prospective buyers. To find out the effect of SEO on increasing the ranking of websites on the google page, it was checked every day for a month, from the 1 st to the 30th of August 2018. The checking of the ranking of websites was performed manually, namely by searching for information about diving in Bali on the google.com page, use the keyword "diving in Bali". The ranking of the websites of Atlantis Dune, Bali Diving, and Scuba Diving Adventure on the Google search engine can be presented as follows:

e-ISSN: 2407-392X. p-ISSN: 2541-0857 


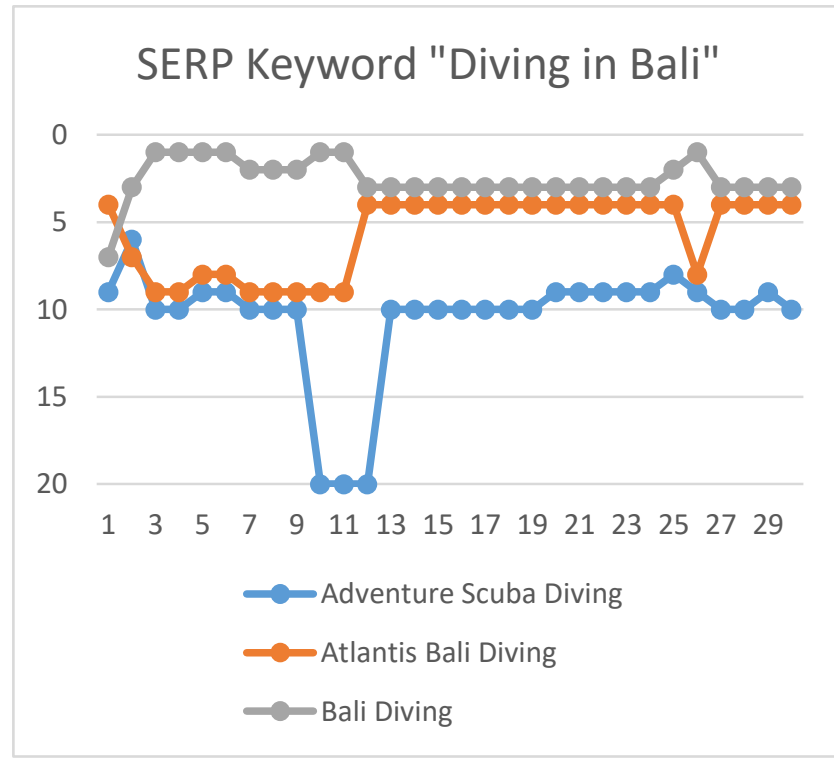

Figure 1. Ranking of Websites of Adventure Scuba Diving, Atlantis Dune, and Bali Diving on Google pages with the keyword "Diving in Bali"

Source: smallseotools.com (2018)

Figure 1 shows that Atlantis Dune and Bali Diving have been ranked quite well on the Google search engine page. Both had static graphics until the end of August 2018. Unlike the two competitors, Adventure Scuba Diving experienced the most obvious ups and downs, until it declined to the second page. If it is viewed from the use of on-page and offpage optimization techniques, Adventure Scuba Diving was indeed still far behind when compared to Atlantis Dune and Bali Diving.

Nevertheless, the global ranking of the three diving companies based on the number of visitors to each website is not too much different. The highest number of visitors is obtained by Atlantis Dune. This is estimated to be caused by the number of http://ojs.unud.ac.id/index.php/eot backlinks that are disseminated through blog posts, social media, online forums, and others. Atlantis Dune is known to be balanced in using on-page and off-page SEO techniques. Although the ranking on the Bali Diving search engine page is superior because it has good website content, Atlantis Dune has more visitors than Bali Diving, because it spreads more links on blogs, articles, online forums, and social media. This then relates to the strong increase in brand awareness resulting from the spread of links on the internet.

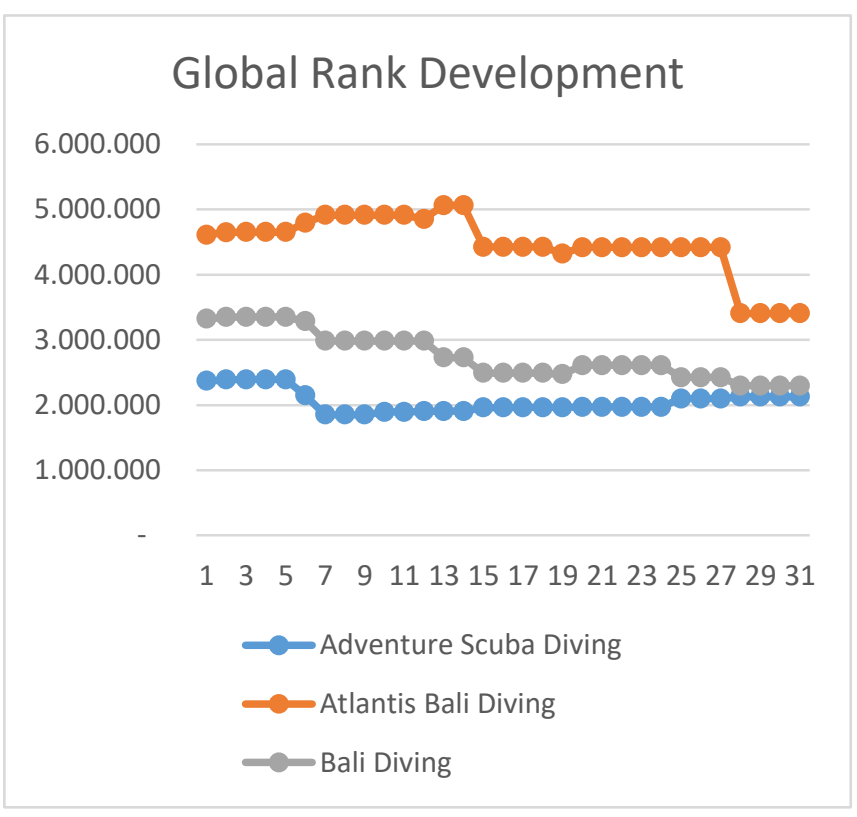

Figure 2. Website Global Ranking of Adventure Scuba Diving, Atlantis Dune, and Bali Diving on Google pages with keywords "Dive in Bali" Source: alexa.com (2018)

\section{Increasing Brand Awareness}

Each respondent of Bali Diving, Adventure Scuba Diving, and Atlantis 
Dune was given questionnaires regarding brand awareness that was measured using a Likert scale. The questionnaire was distributed to a total of 90 respondents, where the total respondents were divided equally to the 3 diving companies studied. Thus, each company allowed us to distribute questionnaires to 30 of their consumers who have purchased diving packages. The following is a summary of the results of a total assessment of 90 consumers of Bali Diving, Adventure Scuba Diving, and Atlantis Dune.

Table 2. Results of the Brand Awareness Questionnaires

\begin{tabular}{|c|c|c|c|c|c|c|c|c|c|}
\hline $\begin{array}{c}\text { Co } \\
\text { mp } \\
\text { any }\end{array}$ & $\begin{array}{c}\text { Indic } \\
\text { ator }\end{array}$ & 1 & 2 & 3 & 4 & 5 & $\begin{array}{c}\text { Tot } \\
\text { al } \\
\text { sco } \\
\text { re }\end{array}$ & $\begin{array}{c}\text { Ind } \\
\text { ex } \\
\text { val } \\
\text { ue }\end{array}$ & $\begin{array}{l}\text { Cate } \\
\text { gory }\end{array}$ \\
\hline $\begin{array}{l}\text { Bali } \\
\text { Div } \\
\text { ing }\end{array}$ & $\begin{array}{l}\text { Top } \\
\text { of } \\
\text { Mind }\end{array}$ & 1 & 2 & 11 & 14 & 2 & 104 & $\begin{array}{l}69.3 \\
\%\end{array}$ & High \\
\hline $\begin{array}{l}\text { Adv } \\
\text { entu } \\
\text { re } \\
\text { Scu } \\
\text { ba }\end{array}$ & $\begin{array}{l}\text { Top } \\
\text { of } \\
\text { Mind }\end{array}$ & 2 & 3 & 12 & 9 & 4 & 100 & $\begin{array}{l}66.6 \\
\%\end{array}$ & High \\
\hline $\begin{array}{l}\text { Atla } \\
\text { ntis } \\
\text { Dun } \\
\text { e }\end{array}$ & $\begin{array}{l}\text { Top } \\
\text { of } \\
\text { Mind }\end{array}$ & 0 & 1 & 6 & 14 & 9 & 121 & $\begin{array}{l}80.6 \\
\%\end{array}$ & $\begin{array}{l}\text { Very } \\
\text { high }\end{array}$ \\
\hline
\end{tabular}

Table 2 shows that Atlantis Dune has a brand awareness level with the highest value category. The use of Atlantis Dune off-page SEO techniques is so powerful that it influences brand awareness on the internet. Bali Diving, which is ranked the highest one on the Google page, is also fairly high in brand awareness on the internet. Likewise with Adventure Scuba Diving, although the Adventure Scuba Diving website occupies the lowest position on Google pages compared to others. This is because the three companies are still on the first page of Google, so the level of brand awareness among the three companies is not much different.

\section{Increasing Product Sales}

The use of SEO not only has an impact on increasing website visibility and brand awareness, but also increasing online sales. From the results of interviews with each company, it was obtained the estimated data of the number of online consumers in 2017. The data is explained in Table 3.

Table 3. Average Number of Consumers of Bali Diving, Atlantis Dune, and Adventure Scuba Diving in 2017

\begin{tabular}{|l|c|c|c|}
\hline Year 2017 & $\begin{array}{c}\text { Bali } \\
\text { Diving }\end{array}$ & $\begin{array}{c}\text { Adventure } \\
\text { Scuba } \\
\text { Diving }\end{array}$ & $\begin{array}{c}\text { Atlantis } \\
\text { Dune }\end{array}$ \\
\hline $\begin{array}{l}\text { Average } \\
\text { Number of } \\
\text { Consumers } \\
\text { Per Month }\end{array}$ & 100 & 77 & 99 \\
\hline $\begin{array}{l}\text { Increased } \\
\text { Number of } \\
\text { Consumers } \\
\text { Per Month }\end{array}$ & $5.2 \%$ & $4.0 \%$ & $4.5 \%$ \\
\hline
\end{tabular}


Each diving company has experienced an increase in sales in accordance with the intensity of the use of SEO techniques. Bali Diving consumers increased by $5.2 \%$ per month, Adventure Scuba Diving increased by $4.0 \%$ per month, and Atlantis Dune consumers increased by $4.5 \%$ per month. It can be concluded that Bali Diving, Adventure Scuba Diving and Atlantis Dune have experienced the increasead of the number of consumers who buy the company's diving packages every month during period 2017. The average number of consumers per month of the three companies is quite high, namely 100 persons for Bali Diving, 77 persons for Adventure Scuba Diving, and 99 persons for Atlantis Dune. An increase in the number of consumers per month can automatically affect the level of corporate income from previous months.

\section{CONCLUSIONS AND SUGGESTION}

From the results above, it can be concluded that the use of SEO has a positive impact on Bali Diving, Atlantis Dune, and Adventure Scuba Diving, as examples of diving companies that use SEO. With maximum application of SEO techniques, the three diving companies have always managed to appear on the first page of Google and compete to introduce brands and to sell diving packages through the internet. Thus the maximum utilization of SEO techniques has a positive effect on increasing website visibility on Google pages, increasing brand awareness, and increasing sales. All positive impacts are related to each other. The higher the website's visibility, i.e. the ranking of the website on the google pages, the higher the brand awareness. The more brand awareness on the internet, the more influential the increase in the number of consumers and online sales. The use of SEO can be concluded as one of the internet marketing strategies that can help companies to grow rapidly through the internet.

The research also recommends that: (1) academic researchers should do further studies about SEO by taking examples of other types of companies in the field of tourism, such as hotels, restaurants and etc. This example can later be used as another reference regarding the use of SEO techniques as an online marketing strategy in the field of tourism. (2) Local people who want to develop business in the field of tourism, in order to be able to compete with foreign companies, it is better to use SEO techniques in offering their services through the internet. 


\section{ACKNOWLEDGMENT}

The author would like to thank Prof. Dr. I Nyoman Darma Putra, M. Litt. as the first supervisor and Dr. Ir. A.A.P. Agung Suryawan Wiranatha, M.Sc. as the second supervisor for their guidance and time given during the research process. The author is also grateful to the three examiners, namely Prof. Dr. I Made Antara, MS., Gde Indra Bhaskara, M.Sc., Ph.D., and Dr. I Wayan Suardana, SST.Par., M. Par for the input and guidance given.

\section{REFERENCES}

Asia Web Direct (2018) 5 Best Dive Sites in Bali - Where to Go Scuba Diving in Bali. Available at: http://www.baliindonesia.com/magazine/5-bestdive-site.htm (Accessed: 12 June 2018).

Hakim, A. W. (2011) Trik Pintar SEO untuk Blog (Smart SEO Tricks for Blogs). Jakarta: PT. Elex Media Komputindo.

Hidayah, A., Sunarti, S. and Hakim, L. (2017) 'Potensi dan Pengembangan Objek Wisata Bahari Tulamben, Kabupaten Karangasem, Bali', Jurnal Administrasi Bisnis, 50(2), pp. 93-98.

Homburg, C., Klarmann, M. and Schmitt, J. (2010) 'Brand awareness in business markets: when is it related to firm performance?', International Journal of Research in Marketing. Elsevier, 27(3), pp. 201-212.
Joubert, R. J. O., Garg, A. K. and Pellissier, R. (2004) 'Measuring business performance: A case study', Southern African Business Review. Sabinet, 8(1), pp. 7-21.

Rahman, S. (2015) Kitab Sakti SEO Cara Mudah Menjadikan Website No.1 di Google (Smart SEO Tricks Easy Ways to Make Website Number 1 on Google). Jakarta: PT. Elex Media Komputindo.

Satibi, A. F., Suharyono, S. and Abdillah, Y. (2017) 'Analisis Pemanfaatan Search Engine Optimization dalam Meningkatkan Penjualan Produk UKM di Pasar Internasional (Studi Kasus pada CV. Ayung Sportindo)', Jurnal Administrasi Bisnis, 50(6), pp. 96-105.

Wiranatha, A. S. et al. (2016) 'Model of Foreign Tourist's Loyalty on Marine Tourism to Visit Bali', International Journal of Multidiciplinary Education Research, 5(3), pp. 1-16.

Wong, J. (2010) Internet Marketing For Beginners. Jakarta: PT. Elex Media Komputindo. 